\title{
Corrigendum: The Comparison of Expressed Candidate Secreted Proteins from Two Arbuscular Mycorrhizal Fungi Unravels Common and Specific Molecular Tools to Invade Different Host Plants
}

\section{OPEN ACCESS}

Edited and reviewed by: Andrea Genre,

Università degli Studi di Torino, Italy

${ }^{*}$ Correspondence:

Christophe Roux

roux@/rsv.ups-t/se.fr

Nicolas Frei dit Frey

frei-dit-frey@lrsv.ups-tlse.fr

${ }^{\dagger}$ Present Address: Nianwu Tang,

Key Laboratory for Plant Diversity and Biogeography of East Asia, Kunming Institute of Botany, Chinese Academy of Sciences, Heilongtan, Kunming,

China

Specialty section: This article was submitted to Plant Microbe Interactions, a section of the journal Frontiers in Plant Science

Received: 08 November 2017 Accepted: 17 November 2017 Published: 08 December 2017

Citation:

Kamel L, Tang N, Malbreil M, San Clemente H, Le Marquer M, Roux C and Frei dit Frey N (2017)

Corrigendum: The Comparison of Expressed Candidate Secreted

Proteins from Two Arbuscular Mycorrhizal Fungi Unravels Common and Specific Molecular Tools to Invade

Different Host Plants.

Front. Plant Sci. 8:2065.

doi: 10.3389/fpls.2017.02065

\begin{abstract}
Laurent Kamel ${ }^{1,2}$, Nianwu Tang ${ }^{1 \dagger}$, Mathilde Malbreil ${ }^{1}$, Hélène San Clemente ${ }^{1}$, Morgane Le Marquer ${ }^{1}$, Christophe Roux ${ }^{1 *}$ and Nicolas Frei dit Frey ${ }^{1 *}$

${ }^{1}$ Laboratoire de Recherche en Sciences Végétales, Université Paul Sabatier - Université de Toulouse, Centre National de la Recherche Scientifique, Castanet-Tolosan, France, ${ }^{2}$ Agronutrition, Laboratoire de Biotechnologies, Labege, France
\end{abstract}

Keywords: Glomeromycota, secretome, comparative transcriptomics, effectors, symbiosis

\section{A corrigendum on}

The Comparison of Expressed Candidate Secreted Proteins from Two Arbuscular Mycorrhizal Fungi Unravels Common and Specific Molecular Tools to Invade Different Host Plants by Kamel, L., Tang, N., Malbreil, M., San Clemente, H., Le Marquer, M., Roux, C., et al. (2017). Front. Plant Sci. 8:124. doi: 10.3389/fpls.2017.00124

In the original article, there was an error in Table S1A concerning Rhizophagus irregularis in planta RNAseq libraries.

The corrected Table S1A has been published as Supplementary material.

Accordingly, an addendum has been made to Materials and Methods section, RNA Production and Sequencing, first paragraph:

“Total RNA extraction and sequencing were performed according to Tisserant et al. (2013) for R. irregularis and Tang et al. (2016) for G. rosea. Apart from ERM of G. rosea where short paired- end sequencing reads were obtained from Illumina Miseq1000 protocols $(2 \times 151 \mathrm{bp})$, all libraries were obtained from Illumina Hiseq2000 protocols $(2 \times 101 \mathrm{bp})$. Library constructions and sequencing were performed on the GeT-PlaGe facility (Toulouse, France), according to standard Illumina protocols. Data are available at NCBI GEO portal (GSE67906 and GSE67911) for G. rosea, and at NCBI Sequence Read Archive (SRR1027885) and at NCBI GEO portal (GSE67926) (-see details on libraries in Table S1A) for R. irregularis. Number of reads per libraries, representativeness of fungal reads in symbiotic tissues and variability of data are presented in Tables S1A, S5A for $R$. irregularis and G. rosea respectively."

The authors apologize for these errors and state that this does not change the scientific conclusions of the article in any way.

The original article has been updated.

Conflict of Interest Statement: The authors declare that the research was conducted in the absence of any commercial or financial relationships that could be construed as a potential conflict of interest.

Copyright $\odot 2017$ Kamel, Tang, Malbreil, San Clemente, Le Marquer, Roux and Frei dit Frey. This is an open-access article distributed under the terms of the Creative Commons Attribution License (CC BY). The use, distribution or reproduction in other forums is permitted, provided the original author(s) or licensor are credited and that the original publication in this journal is cited, in accordance with accepted academic practice. No use, distribution or reproduction is permitted which does not comply with these terms. 